\title{
CLASSIFICATION AND DESCRIPTION OF BONDS
}

\author{
By Frederick A. Cleveland, Ph.D., \\ Of Haskins \& Sells, New York City.
}

A comprehensive basis for the classification of bonds is not to be found in the bond lists nor in current market reports. The names and classes thus arranged are for purposes of convenient reference and usually follow the practice of the local exchange. Generally speaking, bonds receive their titles from one or more of the following characteristics: (I) The character of the corporation using them; (2) the purpose of issue; (3) the nature of security given for payment; (4) the terms of payment, and (5) evidence of ownership and transfer. The first of these five characteristics is used as a basis for general classification. That is to say, quotations are usually arranged under the following heads:

Government-state and national.

Municipal and county.

Railroad, express and steamship companies.

Traction companies.

Gas, electric light, and water companies.

Bank and trust companies.

Investment companies.

Industrials.

Mining companies.

Miscellaneous.

No explanation is needed to an understanding of the significance of these general classifications.

Under the general heads above indicated, each issue, by abbreviation, is given its principal contractual or financial significance. An issue which falls in the general class, "railroads" for example, may be noted as a "unified, sinking fund, joint, or convertible bond." This carries us through the entire range of the classification suggested. The nature of the company places the issue under "railroads"; according to the purpose of the issue it is designated as "unified"; from the nature of the security offered it is called "sinking fund"; having reference to the payor, it is further qualified as "joint"; the terms of payment carry with them the sig$(400)$ 
nificance "convertible." These variances from the general class "railroads" suggest a detailed description of the several kinds of issues under each principle of classification.

\section{Classification According to Purpose of Issue}

Among the many varieties of bonds which take their names from the purpose of issue the following may be noted:

Adjustment borids, brilge bonds, construction bonds, consolidated bonds, car trust bonds, dock and wharf bonds, equipment bonds, extension bonds, founders bonds, ferry bonds, general bonds, improvements bonds, interim bonds, interest bonds, purchase money bonds, refunding bonds, reorganization bonds, revenue bonds, subsidy bonds, terminal bonds, tunnel bonds, temporary bonds, unified bonds.

An adjustment bond is an issue of bonds so named for the reason that the funds obtained from the sale thereof enable a company to adjust its finances to its increased financial needs. It is also a term used to characterize an issue for the purpose of adjusting the interests of two or more persons or corporations. These are usually issued as a result of litigation involving a receivership or other interference with the regular use or management of the property. The property itself being considered ample protection to the several rights of parties, and the company not having the funds available with which to settle without further encumbering the enterprise, bonds are issued to consummate the transaction, release the property, and relieve the management from further legal interference.

Bridge bonds are frequently issued by an independent company organized for the purpose indicated. More often, however, this is not the case. In railroad nomenclature, the bridge bond is issued to procure funds for a costly bridge construction in which one or more roads are interested. If a bridge company is separately incorporated for the purpose of holding the title, the bonds are usually secured not only by a lien on the property but also by an individual or joint guarantee.

Construction bonds are issues pending construction to provide the cash with which to purchase materials and pay for labor. They represent the capital cost of construction. In railroad parlance, the term may indicate an intention later to refund by means of another 
issue. By a construction company they may be issued pending payment on work in progress, and are in the nature of temporary advances on construction, the evidence of which is a serial issue of notes secured by a lien on the construction.

Car trust bonds are the issues of a company, or trustee, intermediate between the car manufacturer and the railroad company. The mantufacturer, wishing to realize the ready cash with which to carry on his further operations, the title to cars desired by a railroad are transferred to the car trustee, who issues to the road a lease or other contract for partial payments; to provide the cash needed by the manufacturer a mortgage on the cars is placed in the hands of a second trustee (usually a trust company) and serial notes or bonds are issued and sold, provisions being made for the periodical payment of the notes by application of money received from the railroad. Usually these notes are in several series, Series "A" being first retired, followed by Series "B," etc., till all are paid and the mortgage is satisfied. Then the intermediary company, having fully paid its obligation to the bondholders and received a release from the trust company of the mortgage, makes an unconditional deed to the railroad for the cars leased or conditionally sold.

Dock and wharf bonds may be issued by several roads having common dock and wharf facilities or by a single road, the purpose being to have a separate and distinct security to offer for new capital with which to build the docks. In such case the dock and wharf property would be owned by a separate company, the stock in which would be held by the parent company.

Equipment bonds are issued for a purpose similar to that of "car trust bonds," the difference being that usually the purchase is made and a direct chattel mortgage is given back as part consideration without the interposition of another vendor or leasing company.

Extension bonds. The qualifying word "extension" has a double significance in bond parlance, the first meaning has reference to an extension of a railroad or other property, as the extension of the main line from one point to another; the second meaning has reference to an extension of time of payment. The latter provision, however, is usually stamped on the original instrument after the contract has been entered into and properly authenticated. 
Founders bonds. In England founders shares are sometimes issued to represent the interest of the promoters of a new company. In some American states such an issue is also permissible under the law. Instead of stock, an arrangement may be made for a special bond issue. This is most frequent in industrial companies, where the founder, wishing to retire from business, will make a transfer, taking at par in bonds such portion of the estimated value of the property or the full value as may be agreed on, the corporation issuing to the new proprietors shares. This enables the old proprietor to obtain a regular income from the enterprise founded by him, and the new proprietors to obtain the benefits of any increased value that may accrue from the introduction of new capital or new methods.

Ferry bonds may be issued by a railroad which has a general mortgage on its properties the provisions of which make it a lien on all property subsequently acquired. If the bonds are issued as a part of the consideration for purchase, only the value of the equity inures to the benefit of the general mortgage bondholders. The same result may obtain by the organization of a subsidiary company to hold the title to the ferry properties.

General bonds. The term "general" when used to indicate purpose is similar in its meaning to "consolidated," "blanket" and "unified." More frequently it is used in relation to the character of security afforded.

Improvement bonds need no description, as the name itself suggests the purpose of the issue.

Interim bonds are issued for the purpose of procuring the funds with which to consummate a transaction, and at the same time to preserve the rights of parties during the interim of arranging the details necessary to final adjustment or settlement. The term is also applied to what is later defined as "temporary bonds."

Interest bonds are issued for the purpose of definitely deferring interest payments due and protecting the property or corporation from the consequences of a default. The new contracts amount to an extension of interest payments without operating as a novation of old contract.

Purchase money bonds is a term commonly used as descriptive of the use of issues as part consideration on purchase of properties. Refunding bonds are issues used for the purpose of exchanging 
for or procuring the funds necessary to purchase or make payment on and retire previous issues.

Reorganization bonds are usually issued as a means of settling the rights of the several parties involved in a receivership and as a means of providing the current funds needed for successful reorganization and the surrender of the property to its corporate managers. This name is also given to issues used for purposes of reorganization not involving receiverships.

Revenue bonds is a term most frequently used as descriptive of issues of municipalities sold to the public for the purpose of procuring funds for current use pending the collection of taxes and other revenue. When issued by the English government they are called "exchequer" bonds. "Revenue" is also at times used as a synonym of "income" in describing the character of security for payment.

Subsidy bonds is a phrase having reference to issues of towns, cities, counties and states, as subsidies for railways and other public service companies. The word "subsidy" may also be used in other relations as descriptive of the purpose of issue.

Terminal bonds are frequently issued by subsidiary companies organized to hold the title to terminal properties. The bonds issued for improvement of terminal facilities like "bridge," "dock and wharf" and "ferry" bonds are usually guaranteed by the private company or companies. The reserve for the separate incorporation and issue may be found in the terms of what would constitute underlying. mortgages were the terminal bonds issued by the parent company.

Tunnel bonds, aside from the significance which the name itself implies, may have attached to them circumstances and conditions similar to "terminals," "bridge," etc.

The term temporary bonds has reference to the character of the stationery on which the bond is printed. Pending the production of engraved or permanent-bonds the evidence of the contract may be a typewritten or cheaply-printed document.

Unified bonds are similar in purpose to "consols," viz., to consolidate and unify the various preceding issues. "Unified" bonds often have reference to prospective as well as past capital needs; if, for example, $\$ 25.000,000$ of bonds had already been issued under a number of different mortgages and it was estimated that $\$ 25,000$,$\infty 00$ more would be needed during the next ten years, the unified 
mortgage and bond issue would not only provide for the refunding and consolidation of all previous issues but also for the issue of the bonds needed for further construction or holding purposes, all bondholders thus enjoying equal rights.

Classification of Bonds According to the Character of Security Provided for Payment

From the point of view of the security given for payment, bonds fall into two general classes, viz., (I) unsecured, and (2) secured. The secured bonds may again be divided into two general classes (a) those having personal security and $(b)$ those secured by liens on specific property. These in turn may be sub-divided as follows :

I. Unsecured.

(a) Government bonds.

(b) Corporate debentures.

II. Secured.

(a) Personal security.

I. Endorsed bonds.

2. Guaranteed bonds.

(a) Guaranteed as to principal.

(b) Guaranteed as to interest.

(c) Guaranteed as to both principal and interest.

(b) Lien security.

I. By character of property pledged.

(a) Real property.

I. Land grant bonds.

2. Real estate bonds.

(b) Personal property.

I. Collateral trust bonds.

2. Sinking fund bonds.

2. By the character or priority of lien.

(a) First, second or third mortgage bonds.

(b) General mortgage bonds.

(c) Blanket mortgage bonds.

(d) Consolidated mortgage bonds.

(e) Income bonds. 


\section{(f) Profit-sharing bonds. \\ ( $g$ ) Dividend bonds.}

3. By the character of the holding participation receipts.

Unsecured bonds, sometimes called "plain" bonds, are credit instruments or unconditional contracts for the payment of money, to the holders of which no collateral contract is made, the payment of which is conditioned on default on the original or credit contract. It is commonly thought that what in the market is doninated a bond is secured. This is error. Some of the best bonds clealt in on the exchanges are in the nature of unsecured promises to pay. They are bought and sold on the open credit of the issuer, in the same manner as are one-name commercial papers. Among these are the issues of the federal and state governments, municipalities, county bonds, etc. The Bank of the United States issued unsecured bonds. In this country practically the only form of security given for the bonds of public corporations is a sinking fund. This may be a cumulating security or it may cover the principal from the date of issue. An instance of such secured municipal bond is found in the issues of the city of Chicago, where, at the time the issues were authorized, a tax was levied for the full amount, payable and collectible by instalments over the life of the bond. Among the unsecured private or corporate bonds are the debentures of railroads. The short time loans to railroads are sometimes floated in the form of serial notes. These are nothing more nor less than unsecured short-time bonds.

Endorsed bonds are those the security for which is a common law guaranty. That is, the contract of security is in the nature of a personal guarantee implied and enforceable in law by the act of writing the name of the guarantor upon the back of the instrument. This term is also used of bonds on the back of which is placed words of writing not properly pertaining to it, but which, according to the rules of the exchange may not be delivered except as an endorsed bond, as for example "This is the property of the Mutual Life Insurance Company."

Guaranteed bonds are those the security for which is a written guarantee, either attached to the credit instrument itself or evidenced by a separate writing. The guarantee differs from the endorsement in that the name of the endorser carries with it an 
unwritten contract the meaning of which is established by common practice and legal precedent, while the guarantee, being expressed in writing, is strictly construed and enforcible only in accordance with the specific terms of the instrument. These guarantees may be for payment of principal or for the payment of interest or for the payment of both principal and interest in case of default of the payor.

Land grant bonds are issues of railroads, the security for which is a mortgage on the lands granted as subsidies by the state and federal governments. Many of the roads procured a large proportion of the funds used by them in construction by means of land grant bond sales, issuing the stock to the promoters, for the enterprise in organizing the project and procuring the subsidies.

Real estate bonds, in railroad parlance, refers to the issue secured by a mortgage on real property not used in the operation of the road. This designation is also used for the issues of real estate corporations. Some of them are issued by private parties secured by a mortgage on real estate improved by means of the funds obtained or flotation of the issue.

Collateral trust bonds are the issues of a corporation the security for which is a lien on other stocks or bonds, or both, deposited with a trustee, usually a trust company, under an agreement setting forth the conditions of the trust.

Sinking fund bonds are issues the security for which is a fund created by contract, usually a cumulating one in the hands of a trustee.

Prior lien, junior lien, first, second and third mortgage bonds are designations having reference to the priority of the rights of several parties holding a lien or mortgage to property held in trust for the payment of bond credit issues in case of default. A prior mortgage bond is also called an "underlying" bond.

General mortgage, blanket mortgage, consolidated mortgage, bonds, so far as they have reference to the nature of security for payment, signify that issues are secured by a general mortgage on properties. The "general mortgage" bond, however, may be secured by a mortgage on properties which have not previously been made subject to lien. The term "blanket mortgage" is frequently employed to indicate a very inferior lien given to secure a floating debt or other previously unsecured obligation. The "con- 
solidated mortgage" is generally used to indicate the security for refunding issues.

An income bond is one of a series of issues the security for the interest payment of which is a lien on the net income of the company issuing it, which may be either cumulative or non-cumulative. The principal may be secured or unsecured. If secured, the security is usually a mortgage junior to all other secured issues, but places the obligation for the payment of principal ahead of unsecured creditors. Some income bond issues have been called "participation" bonds.

Profit-sharing bonds and dividend bonds are terms applied to issues, the holders of which, in addition to interest, are entitled to dividend or profit-sharing rights. This is a form of bond that partakes of the advantages of preferred stock, differing from stock in that it is usually secured and does not convey voting power; it differs from the "straight" bond in that it offers an added and speculative inducement to the purchaser. The issue generally carries with it what may be called a "sub-standard" risk.

Participation receipts are receipts issued by the trustee of a bond syndicate on payment of subscriptions, the effect of which is to entitle the holder to a certain participation in the profits of the syndicate or to a certain proportion of the bonds in distribution.

Classification of Bonds According to Terms of Payment and Retirement of Issues

Among classes of bonds which have reference to the contractual rights of parties looking toward payment and retirement of issues are the following:

I. As to character of payment required.

I. Gold bonds.

2. Silver bonds.

3. Currency bonds.

4. Legal tender bonds.

II. As to option of payor.

I. Redeemable.

(a) At specified time.

(b) Call.

2. Irredeemable. 
III. As to option of payee.
I. Convertible.
2. Annuity.
3. Endowment.

IV. As to character of payor.
I. Joint.
2. Several.

$A$ gold bond is one by the terms of which the payor contracts to deliver the principal and interest in gold coin of the realm and usually specifies the weight and fineness. This gives to the holder a right to demand and receive the specific kind of money described. The contract is seldom enforced, as it may be settled by offer and acceptance of some other form of money, though more usually settlement is made with a transfer of credit by check or draft.

A silver bond is one in satisfaction of which the holder may demand an agreed amount of silver money of a specified weight and fineness. These bonds are common to countries having a silver monetary standard. To this class belonged the old "sterling" bonds of England. At the present time the provision is usually inserted for the supposed benefit of the payor.

Currency bonds were issued during and immediately after the Civil War. Similar bonds have also been issued by other countries where paper money was made legal tender.

Legal tender bonds are those by the terms of which the payor may have the option of paying in any kind of legal tender money; they give to him the benefit of the cheaper form of currency.

Redeemable bonds are those by the terms of which the payor may pay in a specified manner and at a specified time before maturity, $i$. e., before the payee has a right to demand payment. $\operatorname{Re}-$ demption may be at specified times or dates, or it may be "on call." Of the former class were many of the federal government bonds issued during the Civil War. "Call" bonds usually require notice and the payment of a one year's interest or other premium. Many sinking fund bonds are subject to call when a fund of specified amount has accumulated in the hands of a trustee. Redeemable bonds are sometimes called "optional" bonds.

An irredcemable bond is one which contains in the contract no option for payment prior to maturity. 
Convertible bonds are those by the terms of which the holder has a right to exchange or convert at a given rate into other forms of property. The most usual form of conversion right is one which entitles the holder to obtain common or preferred stock at a predetermined rate of exchange. This right gives to the bond a certain speculative value aside from its estimated investment value, based on interest rate and security for payment. Oftentimes the conversion rights of bondholders become an important factor in control and in stock manipulation. Another form of "convertible" is issued by real estate corporations entitling the holder to convert into property according to schedule. A "tax bond" is a form of convertible bond, being convertible into payment for taxes.

Annuity and endozment bonds have taken many different forms and characteristics. Of the old English government bonds many were on an annuity basis, which indefinitely postponed the time for payment of principal and gave to the holder a right to income at a specified rate for a period determinable except by subsequent agreement. Some bonds have annuity and endowment options, the endowment feature providing for a definite number of payments of predetermined amount.

\section{Bonds Classified According to Evidence of Ozonership and Transfer}

Considered from this viewpoint there are three classes, viz., coupon bonds, registered bonds and coupon registered bonds.

Coupon bonds are issues the contracts for payment of interest on which is evidenced by separate coupons or contracts for payment, which fall due consecutively on the interest-paying dates. The coupons may be detached and constitute complete promissory notes in themselves, payable to bearer. The coupons are usually written on small sections of a sheet of paper attached to the principal obligation and as they mature are clipped off and presented for payment. They are frequently presented for payment through a bank as a check or draft would be.

Registered bonds are credit instruments the interest obligation in which is expressed in the same writing or paper as in a promissory note, the ownership of the bond being registered as a means of protecting the payee against loss, necessitating a formal transfer and registration to transfer the title when the old instrument is canceled and a new one is issued. Interest is payable by money 
delivery or by check sent by mail to the address of the registered holder. Notice should be given of any change in address.

Registered coupon bonds are issues the principal of which is registered, the coupons being made payable to bearer.

In practice a single bond issue may have any number of these many distinguishing characteristics, so long as they are not in conflict. When applied to specific issues the number of classes may be equal to the mathematical possibility of the several elements described in combination. The advantage of the analytical classification here used is that by classifying and defining bond characteristics the terminology may be understood in any combination used. 